\title{
The regeneration of the tail fin actinotrichia of carp (Cyprinus carpio, Linnaeus, 1758) under the action of naproxen
}

\author{
Böckelmann, PK. and Bechara, IJ.* \\ Laboratório de Histofisiologia e Histopatologia Experimental em Animais Ectotérmicos, \\ Departamento de Histologia e Embriologia, Instituto de Biologia, \\ Universidade Estadual de Campinas - UNICAMP, \\ CP 6109, CEP 13083-970, Campinas, SP, Brazil \\ *e-mail: ibechara@unicamp.br
}

Received June 12, 2008 - Accepted September 19, 2008 - Distributed November 30, 2009

(With 12 figures)

\begin{abstract}
A conglomerate of small, rigid, fusiform spicules known as actinotrichia sustains the edge of tail fins of teleost. After amputation, these structures show an extremely fast regenerative capacity. In this study we observed the effect of a nonsteroidal anti-inflammatory drug, naproxen, used in the treatment of degenerative articular diseases, during the process of actinotrichia regeneration. For this purpose, regenerating tissue from animals in contact with the drug was submitted to histochemical and ultrastructural analysis in comparison to tissue from animals under normal conditions, i.e., not in contact with the drug in question. Actinotrichia regeneration was similar in both animals, indicating that naproxen, at the dose used in the present study, did not interfere with actinotrichia synthesis during the regenerative process of the tail fin. This could be because naproxen did not influence the expression of the genes required for the regeneration process, such as the Sonic hedgehog (Shh) gene, which is involved in actinotrichia formation.
\end{abstract}

Keywords: caudal fin, tissue regeneration, elastoidin, nonsteroidal anti-inflammatory drug, fish.

\section{A regeneração das actinotriquias da nadadeira caudal da carpa (Cyprinus carpio, Linnaeus, 1758) sob a ação do naproxeno}

\begin{abstract}
Resumo
A borda da nadadeira caudal de teleósteo é sustentada por um conglomerado de espículas pequenas, rígidas e fusiformes chamadas actinotriquias. Essas estruturas, após a amputação, apresentam uma capacidade regenerativa extremamente rápida. Neste trabalho estudamos o efeito de uma droga anti-inflamatória não esteroide, o naproxeno, utilizada no tratamento de doenças articulares degenerativas, durante o processo de regeneração da actinotriquia. Para isso foram feitas análises histoquímicas e ultraestruturais do tecido em regeneração de animais em contato com a droga comparada com animais em condições normais, ou seja, sem contato com a droga em questão. Os animais em contato com a droga apresentaram a regeneração da actinotriquia de modo semelhante ao dos animais mantidos em condições normais, indicando que o naproxeno, na dose utilizada neste trabalho, não interferiu na síntese das actinotriquias durante o processo regenerativo da nadadeira caudal. Isto talvez seja porque o naproxeno não tenha influenciado a expressão dos genes necessários para o processo de regeneração, tal como o gene Sonic hedgehog (Shh), que está envolvido na formação da actinotriquia.
\end{abstract}

Palavras-chave: nadadeira caudal, regeneração tecidual, elastoidina, droga anti-inflamatória não esteroide, peixe.

\section{Introduction}

The tail fin of teleost fish is a symmetric organ composed of multiple skeletal rays, the lepidotrichia (Becerra et al., 1983; Géraudie and Singer, 1992; Montes et al., 1982; Santamaría and Becerra, 1991). These rays originate from the base of the fin and they spread distally, towards the edge. Extending from the distal portion of each lepidotrichia towards the edge of the tail fin there

is a cluster of small, fusiform, rigid and slender spicules called actinotrichia, which support the border of the tail fin (Becerra et al., 1983). Both the lepidotrichia and actinotrichia are surrounded by connective tissue containing blood vessels, nerves, pigment cells and fibroblasts and covered by a multistratified epidermis (Becerra et al., 1983). 
Lepidotrichia are structures composed of collagen type II fibrils surrounded by a fundamental mineralised substance, the major component of which is chondroitin sulfate (Montes et al., 1982). Actinotrichia are formed of hyperpolymerised macrofibrils of elastoidin, a protein with characteristics similar to those of collagen (Gross and Dumsha, 1958; Marí-Beffa et al., 1989).

The regeneration suffered by the fin after amputation is the time when the control mechanisms of form and structure start functioning. The phases of the process are: formation of a multistratified epidermal layer, disorganisation and distal migration of mesenchymal cells near to the amputation plane, proliferation of these mesenchymal cells to form the blastema, continuous proliferation of the distal blastema to facilitate growth, and differentiation of the proximal blastemal cells to replace its lost structures (Akimenko et al., 2003; Géraudie and Singer, 1992; Goss and Stagg, 1957; Johnson and Weston, 1995; Poss et al., 2000; Santamaría and Becerra, 1991; SantosRuiz et al., 2002).

Fin regeneration in teleost fish is extremely sensitive to external physical and chemical factors, such as temperature variations (Johnson and Weston, 1995), action of some environmental contaminants such as TCDD (2,3,7,8-Tetrachlorodibenzo-p-dioxin) (Fingerman, 1980; Zodrow and Tanguay, 2003) and the action of some drugs, for example betaaminopropionitrile, penicillamine, dexamethasone and acetylsalicylic acid, which inhibit collagen synthesis and consequently regeneration (Bechara et al., 2003; 2000).

Naproxen is a nonsteroidal anti-inflammatory drug derived from propionic acid, which has three main types of action: antipyretic, analgesic and anti-inflammatory. It is used in the treatment of osteoarthritis, rheumatoid arthritis, gout and rheumatism of soft tissue and is also indicated for periarticular and musculoskeletal diseases (Hanson et al., 2005; Mendias et al., 2004; Ratcliffe et al., 1993).

However, there are controversial reports in the literature about the action of naproxen on the connective tissue, especially regarding collagen synthesis (Bjelle and Eronen, 1991; Goodman et al., 2002; Ratcliffe et al., 1993; Riley et al., 2001; Smith et al., 1995; Solheim et al., 1986; Srinivas et al., 1994). Muscará et al. (2000) observed that naproxen decreased the deposition of collagen when administered in the healing of tissue wounds. In addition, Sadowski and Steinmeyer (2001) verified that naproxen interfered with the expression of mRNA of metalloproteinase- 1 so as to reduce its activity, thus interfering with the production of collagen type II by chondrocytes of bovine articular cartilage. In contrast, administration of naproxen to arthritic animals accelerated the synthesis of collagen (Arumugham and Bose, 1981).

Since actinotrichia are formed of a protein with collagen-like characteristics and have the ability to regenerate quite rapidly, and since there are controversial thoughts in the literature regarding the action of naproxen on the extracellular matrix, more precisely collagen synthesis, the objective of the present study was to observe the possible effects of this drug on actinotrichia regeneration.

\section{Materials and Methods}

\subsection{Animals}

Eighty carp alevins, Cyprinus carpio, obtained from a fish farm, weighing on average $1.5 \mathrm{~g}$ and measuring on average $4 \mathrm{~cm}$ in length, were used in this experiment. The fish were maintained in quarantine in plastic aquaria with clean dechlorinated water at $26{ }^{\circ} \mathrm{C}$ with constant aeration, and fed daily with appropriate fish feed.

\subsection{Experiment}

Two glass aquaria, each containing $10 \mathrm{~L}$ of water, were prepared at the beginning of the experiment. The water was clean and dechlorinated, the temperature maintained at $26^{\circ} \mathrm{C}$, the $\mathrm{pH}$ at 8.0 and under constant aeration. A dose of $15.6 \mathrm{mg} . \mathrm{L}^{-1}$ of Naproxen (SYNTEX, Brazil) was dissolved in the water of one of the aquaria. The fish in the other aquarium, containing only water, served as the control group. Eighty alevins were anaesthetised with benzocaine (SYNTH, Brazil) (1:10000) and their tail fins were amputated transversally (in the dorso-ventral direction) at a distance of $3 \mathrm{~mm}$ from the tail muscle peduncle using a sharp razor (according to Becerra et al., 1996). After amputation, the fish were divided into two groups of 40 animals each. One group was placed in the aquarium containing dissolved naproxen and the other was placed in the control aquarium. The fish were left in these aquaria until regeneration occurred. They were then anaesthetised, sacrificed and the regenerating fins excised and fixed at intervals of 1, 2, 4, 5, 6, 8, 10 and 12 days after amputation, using 5 specimens for each time interval.

\subsection{Histology}

\subsubsection{Histochemical process}

The regenerating fins were fixed in Bouin's solution for 6 hours and embedded in paraffin. $6 \mu \mathrm{m}$ transversal fin sections were stained with Picrosirius-Hematoxylin and observed and photographed under microscopes (Nikon Eclipse E800, Japan) using conventional light and polarised light. The regenerating fins collected at intervals of 4, 6 and 8 days after amputation (days selected due to representation in the whole process of tail fin regeneration) had their images analysed using an image analyser (Image Pro-Plus, version 4.1.12, USA). The morphometric analyses were done according to Böckelmann and Bechara (2007).

\subsubsection{Ultrastructural process}

Small fragments of regenerating fins were fixed in Karnovsky for 4 hours at $4{ }^{\circ} \mathrm{C}$, washed with a $0.1 \mathrm{M}$ phosphate buffer solution ( $\mathrm{pH} 7.4$ ) containing $7.5 \%$ sac- 
charose and subsequently postfixed with $1 \%$ osmium solution in $0.2 \mathrm{M}$ phosphate buffer for 1 hour at $4{ }^{\circ} \mathrm{C}$. The samples were then washed with glycosated saline, dehydrated with increasing acetone concentrations, preembedded in a mixture of acetone and epon (1:1) for 3 hours and embedded in pure epon for 24 hours. The tissue fragments included, transversally to the rays, were polymerised in an incubator at $60{ }^{\circ} \mathrm{C}$ for 48 hours. Semifine sections $(1 \mu \mathrm{m})$ were obtained using a LEICA ultramicrotome (Germany) and stained in hot Toluidine Blue. Further ultra-fine sections $(60-70 \mathrm{~nm})$ were subsequently obtained, contrasted with uranyl acetate and lead citrate, and examined and micrographed in a transmission electron microscope (LEO 906, Germany).

\section{Results}

Regeneration in the naproxen-treated fish proceeded in a similar manner to the control fish. Restoration of the lost tissue started immediately after the amputation of the tail fin. Regeneration of the epidermis, connective tissue, lepidotrichia and actinotrichia proceeded as reported in the literature (Becerra et al., 1996).

One day after amputation, the epidermal cells completely covered the cut edge. On the second day a blastema began to form just below the regenerating epidermis.

Actinotrichia were initially observed 4 days after excision of the fin, in other words, after 4 days of regeneration (4D.R.). Their regeneration started in the distal region of the fin, on the inside of the connective tissue matrix adjacent to the epidermis. They were very thin and arranged in bilateral lines, as expected (see Figure 1 and Figure 2).

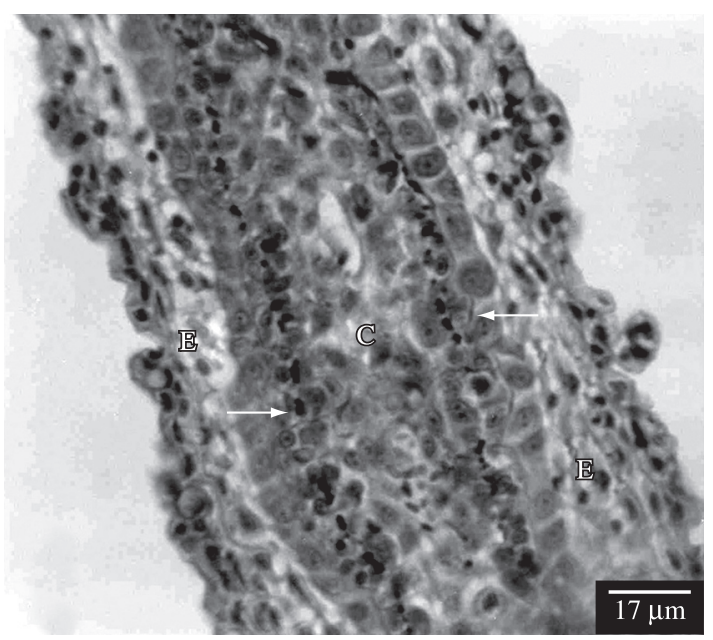

Figure 1. Transversal section of the distal region of a control animal regenerating tail fin, 4 days after amputation (4 D.R.). Observe the epidermis (E), the connective tissue (C) and the regenerating actinotrichia (arrows). Picrosirius-Hematoxylin.
Connective tissue cells, similar to fibroblasts, were observed near the regenerating actinotrichia, indicating that probably these are the cells involved in the synthesis of elastoidin. Cytoplasmic prolongations of these cells, partially surrounding the actinotrichia, could also be observed (see Figures 3 and 4). When observed under microscope with conventional light, these cells presented basophilic cytoplasm, and when observed undertransmission electron microscope, they presented a large amount

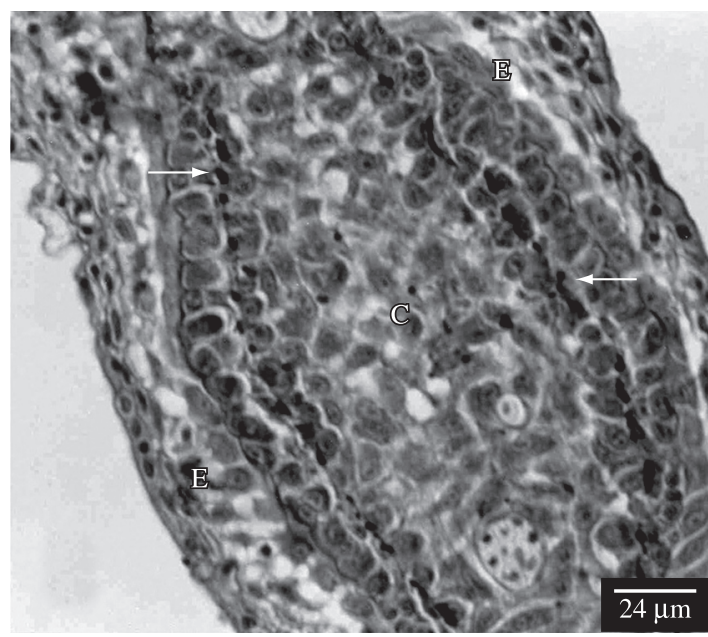

Figure 2. Transversal section of the distal region of a naproxen-treated animal tail fin after 4 days of regeneration. Observe the same structures as in Figure 1. Picrosirius-Hematoxylin.

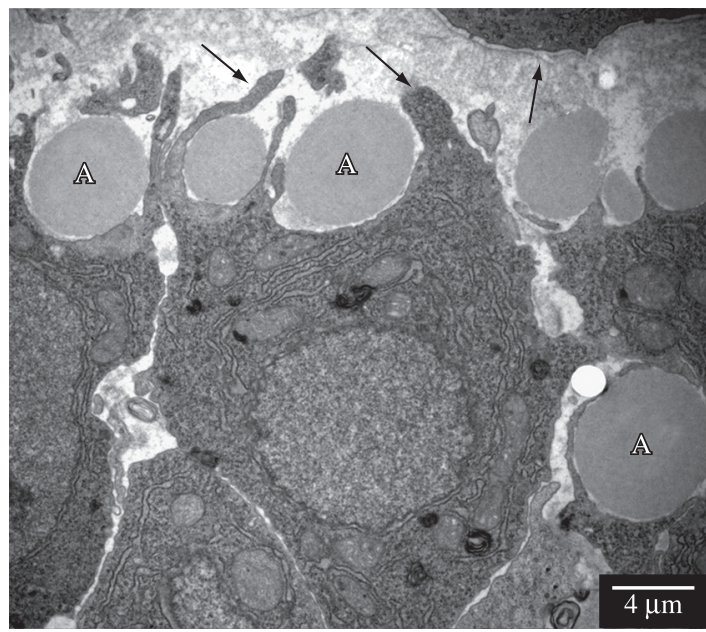

Figure 3. Electron micrograph of a transversal section of a control animal tail fin after 6 days of regeneration. Observe the regenerating actinotrichia (A) surrounded by cytoplasmic processes of connective tissue cells, similar to fibroblasts (arrows). Observe the basal lamina of the epidermis (arrowhead). 
of rough endoplasmic reticulum (see Figures 5, 6 and $10)$, suggesting their involvement in the synthesis of proteins necessary for the formation of actinotrichia.

The actinotrichia became increasingly thicker after $5,6,8,10$ and 12 days of regeneration, due to elastoidin synthesis, until they reached their normal size (see Figures 7, 8, 9 and 10).

Longitudinal sections of the actinotrichia, when observed under the transmission electron microscope, showed that these structures, like the collagen, also presented a transversal striation pattern (see Figures 5 and 6), and when observed under polarised light using

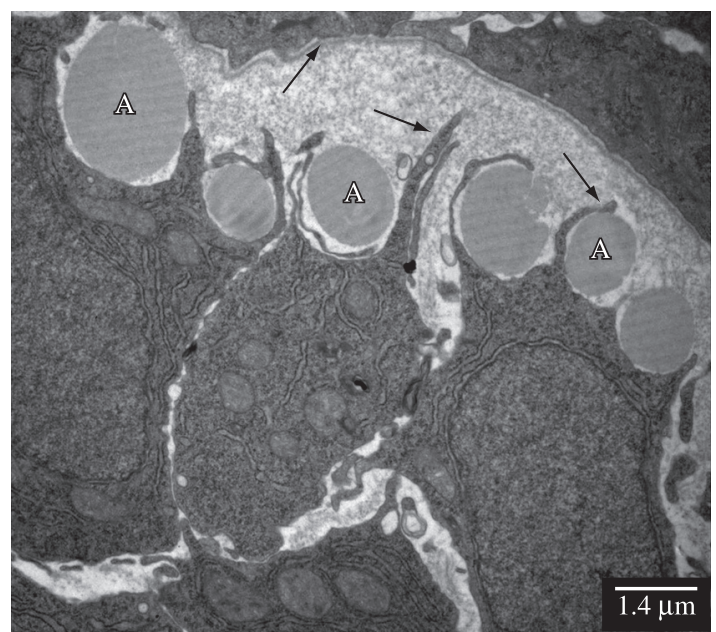

Figure 4. Electron micrograph of a transversal section of a treated animal tail fin after 6 days of regeneration. Observe the same structures as in Figure 3.

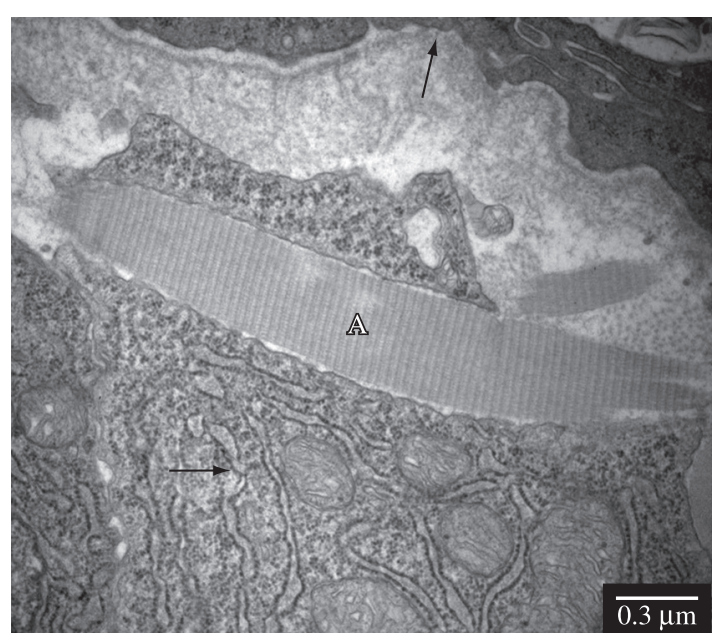

Figure 5. Electron micrograph of a transversal section of a control animal tail fin after 6 days of regeneration. Observe the longitudinal section of the actinotrichium and the regular transversal striation characteristic of collagen proteins (A). Note the amount of rough endoplasmic reticulum in the cell cytoplasm involved in the synthesis of the actinotrichium (arrow) and the basal lamina of the epidermis (arrowhead). the Picrosirius-Polarization method, which is a histochemical method for the detection of collagen in tissue sections, the normal birefringence was greatly increased, thus demonstrating their collagen nature (see Figures 11 and 12).

The morphometric analysis confirmed quantitatively no significant difference $(\mathrm{p}>0.05)$ between the total area of regenerate region of both the control and naproxen treated fishes, as shown in Böckelmann and Bechara (2007).

\section{Discussion}

The teleost tail fin is composed of two structural units known as lepidotrichia and actinotrichia. The acti-

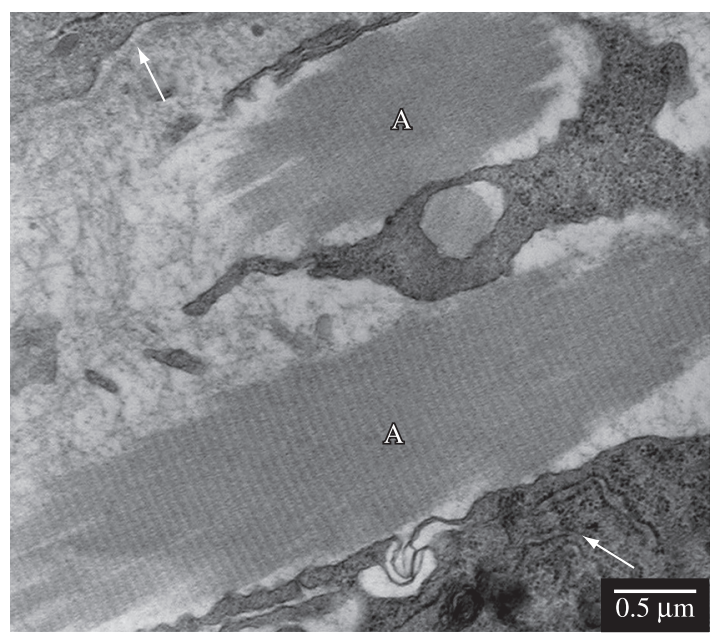

Figure 6. Electron micrograph of a transversal section of a treated animal tail fin after 6 days of regeneration. Observe the same structures as in Figure 5.

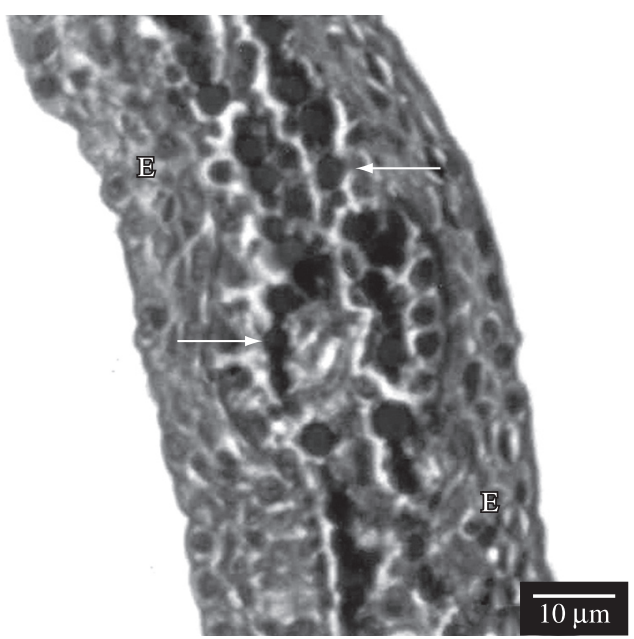

Figure 7. Transversal section of a control animal regenerating tail fin, 10 days after amputation (10 D.R.). Observe the epidermis (E) and the regenerating actinotrichia (arrows). Picrosirius-Hematoxylin. 


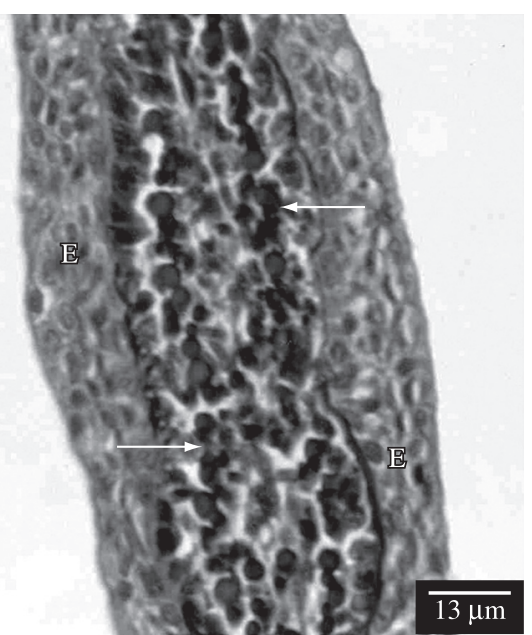

Figure 8. Transversal section of a treated animal regenerating tail fin, 10 days after amputation (10 D.R.). Observe the same structures as in Figure 7. Picrosirius-Hematoxylin.

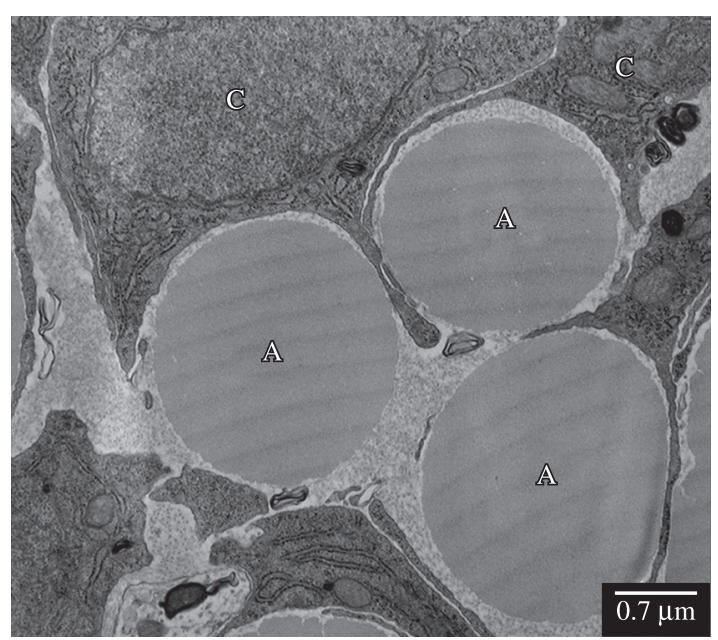

Figure 9. Electron micrograph of a transversal section of a control animal tail fin, 10 days after amputation (10 D.R.). Observe the actinotrichia in an advanced regeneration stage (A) and the cells involved in their synthesis (C).

notrichia form a group of small, rigid, fusiform spicules, found at the apex of each lepidotrichium (Marí-Beffa et al., 1989). When they suffer injury or are amputated, the fins of the teleost fish show a capacity to quickly regenerate its lost structures. Both lepidotrichia and actinotrichia are formed during this regenerative process known as epimorphic regeneration, a process involving the presence of a proliferative mass of pluripotent, progenitorial cells denominated the blastema, and the reconstitution of the tissue complex surrounding multiple cell types (Akimenko et al., 2003).

The actinotrichia are formed from hyperpolymerised macrofibrils of elastoidin, a protein with characteristics similar to those of collagen (Gross and Dumsha, 1958;

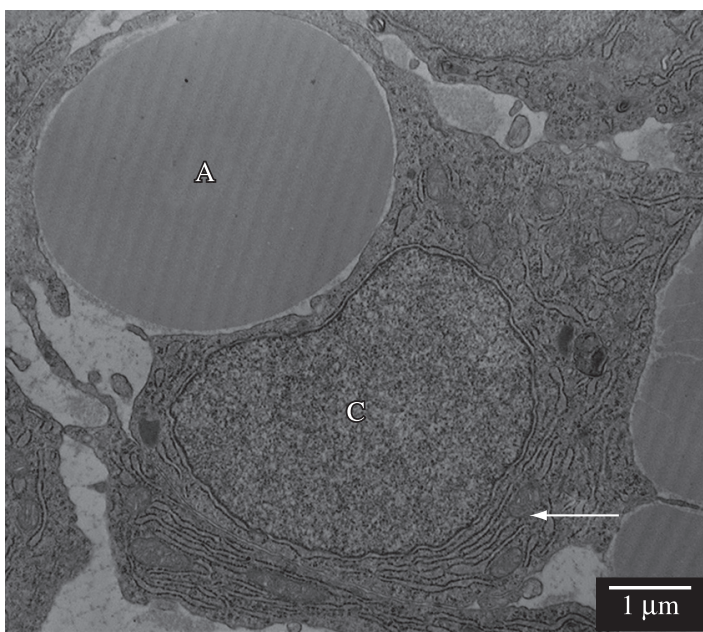

Figure 10. Electron micrograph of a transversal section of a treated animal tail fin, 10 days after amputation (10 D.R.). Observe the same structures as in Figure 9. Note the considerable amount of rough endoplasmic reticulum within the cell cytoplasm (arrow).

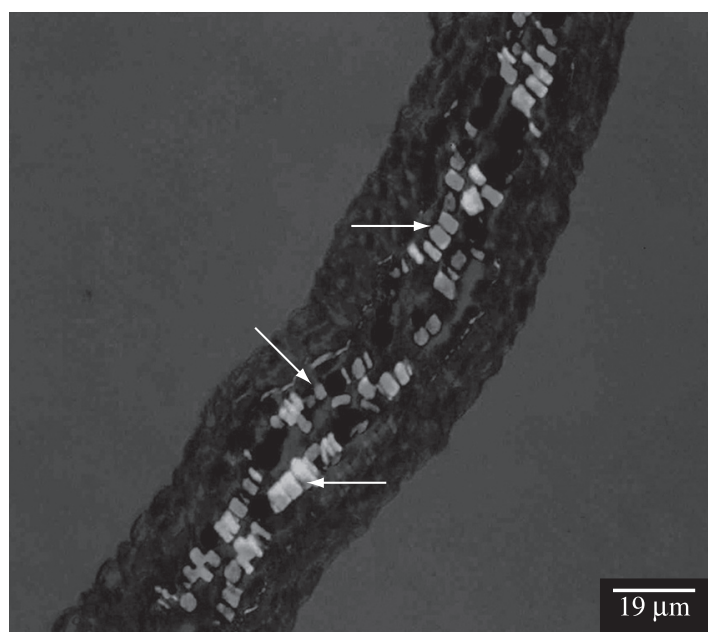

Figure 11. Transversal section of a control animal tail fin after 12 days of regeneration, stained with Picrosirius-Hematoxylin and observed under polarized light. The arrows indicate the regenerating actinotrichia, bright against a dark background. Observe the presence of transversal (arrowhead) and oblique (arrows) actinotrichia.

Marí-Beffa et al., 1989). The collagen nature of elastoidin was determined from the fact that when viewed under polarised light using the Picrosirius-Polarization method, the normal birefringence of these structures was greatly increased (Junqueira et al., 1979), in addition to the fact that the transmission electron microscope showed that the actinotrichia presented a transversal striation pattern characteristic of collagen (Becerra et al., 1996), also observed in the present study. Biochemical analyses show 


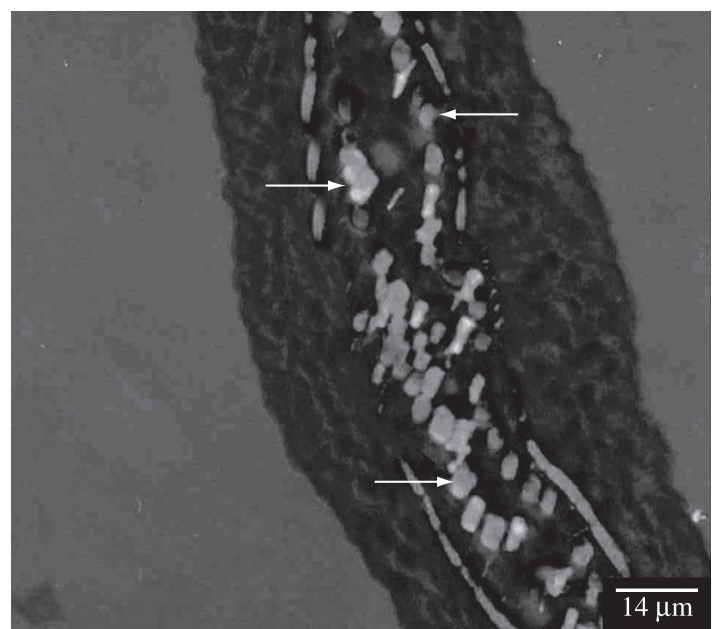

Figure 12. Transversal section of a treated animal tail fin after 12 days of regeneration, stained with PicrosiriusHematoxylin and observed under polarised light. Observe the same structures as in Figure 11.

that elastoidin presents two different fractions: a collagenic (containing glycine, prolyne and hidroxiprolyne) and a non collagenic (the elastoidin richer in tirosyn than collagen) (Bouvet, 1974; Gross and Dumsha, 1958).

Actinotrichia are synthesised distally and are maintained by a continuous turnover movement, which means that the regeneration of these structures can be described by the form of the synthesis and degradation of elastoidin, seen as a regulatory mechanism of the number and distribution of actinotrichia (Marí-Beffa et al., 1989). This mechanism of synthesis and translocation was not affected by the naproxen at the dose used in the present study, neither the regeneration of the structures nor the birefringence and the striation pattern, as observed by light microscopy, transmission electron microscopy and also by Böckelmann and Bechara, (2007) through morphometric analysis, who evaluated the total regenerated area.

It is known that fin regeneration in teleosts is intimately related to the expression of some genes (Akimenko et al., 1995; Borday et al., 2001; Brulfert et al., 1998; Géraudie et al., 1998; Monnot et al., 1999; Poss et al., 2000b; White et al., 1994), and that the inhibition of these genes could alter the configuration of the newly formed fin (Laforest et al., 1998; Poss et al., 2000a). Quint et al. (2002) investigated the effects of cyclopamine, an alkaloid that blocks the Hedgehog $(H H)$ transduction signal, under the expression of the Shh signalling genes, and observed a reduction in fin regeneration followed by inhibition as well as the formation of little or no actinotrichia. These effects were accompanied by a reduction in cell proliferation within the blastema and a reduction in its size.

According to the results of the present research, naproxen in the dose applied did not affect the regeneration of the actinotrichia. This could be because naproxen did not influence the expressions of the genes required for the regeneration process, such as the Sonic hedgehog (Shh) gene, that is involved in actinotrichia formation.

According to reports in the literature (Arumugham and Bose, 1981; Goodman et al., 2002; Muscará et al., 2000; Ratcliffe et al., 1993; Sadowski and Steinmeyer, 2001; Smith et al., 1995; Solheim et al., 1986; Srinivas et al., 1994), naproxen may affect, or not, the collagen synthesis in mammals depending on the dose applied. Böckelmann and Bechara (2004) studied the effect of naproxen on the lepidotrichial matrix of the carp tail fin, at a dose of 20.8 and $10.4 \mathrm{mg} . \mathrm{L}^{-1}$. The dose of $20.8 \mathrm{mg} . \mathrm{L}^{-1}$ was lethal for all fish, while the dose of $10.4 \mathrm{mg} . \mathrm{L}^{-1}$ showed no alterations in the synthesis, deposition and organisation of collagen fibrils. Thus the objective of this study was to evaluate the intermediate dose of $15.6 \mathrm{mg} . \mathrm{L}^{-1}$ between the lethal dose $20.8 \mathrm{mg} . \mathrm{L}^{-1}$ and that failing, to alter the regeneration of the carp tail fin (10.4 mg.. $\left.\mathrm{L}^{-1}\right)$.

The first indication of actinotrichia regeneration in both the control and naproxen treated animals was observed on the fourth day after excision (4 days of regeneration), and on the following days (5, 6, 8, 10 and 12 days), the structure was seen to increase in thickness, becoming more and more evident and occupying a distal position during the whole process. In the present study, the fish treated with $15.6 \mathrm{mg} . \mathrm{L}^{-1}$ of naproxen presented no alteration in the regeneration of the tail fin actinotrichia when compared to the control fish. Studies conducted by Böckelmann and Bechara (2007), using the same dose of $15.6 \mathrm{mg} . \mathrm{L}^{-1}$ of naproxen, showed no effect in the synthesis of the lepidotrichial collagen during the regenerative process. Since there are controversies in the literature about the effect of naproxen in collagen synthesis and considering that the protein elastoidin presents similarities and differences to the protein collagen, our aim in this study was to verify if the same dose of naproxen already tested on the lepidotrichial collagen would not interfere with the synthesis of elastoidin during actinotrichia regeneration.

Bechara et al. (2003) observed that aspirin, a nonsteroidal anti-inflammatory drug like naproxen, inhibited actinotrichia formation, and they suggested that this inhibition could have been because the aspirin probably interfered with the Shh signalling pathway. Although aspirin and naproxen are both members of the same group of non-steroidal anti-inflammatory drug, both inhibiting cyclooxygenases 1 and 2, the difference in action of the two drugs on actinotrichia regeneration may have been due to variations in how these pharmacological agents act locally or are metabolised, leading to variable activities within the same organ.

We emphasise, therefore, the importance of studying morphology and the regeneration of the actinotrichia. Its fast synthesis and the regeneration of the protein elastoidin associated to the use of tools such as light microscopy and transmission electron microscopy make of them 
a good model, easy to study the action of drugs that can interfere in its regenerative process.

Since the fish treated with naproxen at a dose of $15.6 \mathrm{mg} . \mathrm{L}^{-1}$, did not present alterations in the regeneration of the actinotrichia, and the morphometric analysis showed that there were no significant differences in relation to the total area of the fin regeneration, it would be interesting to execute, in the future, experiments with higher doses between the dose of $15.6 \mathrm{mg} . \mathrm{L}^{-1}$ and the lethal dose of $20.8 \mathrm{mg} . \mathrm{L}^{-1}$.

Acknowledgements - The authors are grateful to CAPES/ DS and to the UNICAMP Teaching and Research Support Foundation (FAEP/UNICAMP) for their financial support of this research. The authors also wish to thank the "Recanto dos Peixes" Fishing Club for providing the fish, and Sr. Baltazar Pereira de Paula for technical assistance with the fish.

\section{References}

AKIMENKO, M., JOHNSON, S., WESTERFIELD, M. and EKKER, M., 1995. Differential induction of four msx homeobox genes during fin development and regeneration in zebrafish. Development, vol. 121, no. 2, p. 347-357.

AKIMENKO, M., MARÍ-BEFFA, M., BECERRA, J. and GÉRAUDIE, J., 2003. Old questions, new tools, and some answers to the mystery of fin regeneration. Developmental Dynamics, vol. 226, no. 2, p. 190-201.

ARUMUGHAM, R. and BOSE, S., 1981. Effect of indomethacin and naproxen on the metabolism of collagen in adjuvant-induced arthritis. Scandinavian Journal of Rheumatology, vol. 10, no. 3, p. 161-167.

BECERRA, J., JUNQUEIRA, LCU., BECHARA, IJ. and MONTES, GS., 1996. Regeneration of fin rays in teleosts: a histochemical, radioautographic, and ultrastructural study. Archives of Histology and Cytology, vol. 59, no. 1, p. 15-35.

BECERRA, J., MONTES, GS., BEXIGA, SRR. and JUNQUEIRA, LCU., 1983. Structure of the tail fin in teleosts. Cell and Tissue Research, vol. 230, no. 1, p. 127-137.

BECHARA, IJ., BÖCKELMANN, PK., MONTES, GS. and CRUZ-HÖFLING, MA., 2003. Inhibition of caudal fin actinotrichia regeneration by acetylsalicylic acid (aspirin) in teleosts. Brazilian Journal of Morphological Sciences, vol. 20, no. 2 , p. 67-74.

BECHARA, IJ., JOAZEIRO, PP., MARÍ-BEFFA, M., BECERRA, J. and MONTES, GS., 2000. Collagen-affecting drugs impair regeneration of teleost tail fins. Journal of Submicroscopic Cytology and Pathology, vol. 32, no. 2, p. $273-280$

BJELLE, A. and ERONEN, I., 1991. The in vitro effect of six NSAID on the glycosaminoglycan metabolism of rabbit chondrocytes. Clinical and Experimental Rheumatology, vol. 9, no. 4, p. 369-374.

BÖCKELMANN, PK. and BECHARA, IJ., 2004. Effect of naproxen on tail fin regeneration in teleost. Journal of Submicroscopic Cytology and Pathology, vol. 36, no. 1, p. 55-64.

BÖCKELMANN, PK. and BECHARA, IJ., 2007. Histochemical and ultrastructural study of the action of naproxen on tail fin regeneration of teleost. Brazilian Journal of Morphological Sciences, vol. 24, no. 1, p. 17-24.

BORDAY, V., THAERON, C., AVARON, F., BRULFERT, A., CASANE, D., LAURENTI, P. and GÉRAUDIE, J., 2001. Evx 1 trascription in bony fin rays segment boundaries leads to a reiterated pattern during zebrafish fin development and regeneration. Developmental Dynamics, vol. 220, no. 2, p. 91-98.

BOUVET, J., 1974. Différenciation et ultrastructure du squelette distal de la nageoire pectorale chez la truite indigene (Salmo trutta fario L.). II. Différenciation et ultrastructure des lépidotriches. Archives D' Anatomie Microscopique et de Morphologie Experimentale, vol. 63, no. 4, p. 323-335.

BRULFERT, A., MONNOT, M. and GÉRAUDIE, J., 1998. Expression of two even-skipped genes eve 1 and evx 2 during zebrafish fin morphogenesis and their regulation by retinoic acid. The International Journal of Developmental Biology, vol. 42, no. 8, p. 1117-1124.

FINGERMAN, SW., 1980. Differences in the effect of fuel oil, and oil dispersant, and three polichiorinated biphenyls on fin regeneration in the gulf coast killifish, Fundulus grandis. Bulletin of Environmental Contamination and Toxicology, vol. 25 , no. 2, p. 234-240.

GÉRAUDIE, J. and SINGER, M., 1992. The fish fin regeneration. In SAUER, HW. (Ed.). Keys to regeneration. Monographs in Developmental Biology, vol. 23, p. 62-72.

GÉRAUDIE, J., AKIMENKO, M. and SMITH, M., 1998. The dermal skeleton. In FERRETTI, P. and GÉRAUDIE, J. (Eds.). Cellular and molecular basis of regeneration: from invertebrates to human. Chichester: John Wiley and Sons. p. 167-185.

GOODMAN, S., MA, T., TRINDADE, M., IKENOUE, T., MATSUURA, I., WONG, N., FOX, N., GENOVESE, M., REGULA, D. and SMITH, L., 2002. COX-2 selective NSAID decreases bone ingrowth in vivo. Journal of Orthopaedic Research, vol. 20, no. 6, p. 1164-1169.

GOSS, R. and STAGG, M., 1957. The regeneration of fins and fin rays in Fundulus heteroclitus. Journal of Experimental Zoology, vol. 136, no. 3, p. 487-507.

GROSS, J. and DUMSHA, B., 1958. Elastoidin: a twocomponent member of the collagen class. Biochimica et Biophysica Acta, vol. 28, no. 2, p. 268-270.

HANSON, C., WEINHOLD, P., AFSHARI, H. and DAHNERS, L., 2005. The effect of analgesic agents on the healing rat medial collateral ligament. The American Journal of Sports Medicine, vol. 33 , no. 5, p. 674-679.

JOHNSON, S. and WESTON, J., 1995. Temperature-sensitive mutations that cause stage-specific defects in zebrafish fin regeneration. Genetics, vol. 141, no. 4, p. 1583-1595.

JUNQUEIRA LCU., BIGNOLAS, G. and BRENTANI, RR., 1979. Picrosirius staining plus polarization microscopy, a specific method for collagen detection in tissue sections. Histochemical Journal, vol. 11, no. 4, p. 447-455.

LAFOREST, L., BROW, C., POLEO, G., GÉRAUDIE, J., TADA, M., EKKER, M. and AKIMENKO, M., 1998. Involvement of the Sonic Hedgehog, patched 1 and bmp2 genes in patterning of the zebrafish dermal fin rays. Development, vol. 125 , no. 21 , p. $4175-4184$. 
MARÍ-BEFFA, M., CARMONA, M. and BECERRA, J., 1989. Elastoidin turnover during tail fin regeneration in teleosts: a morphometric and radioautographic study. Anatomy and Embryology, vol. 180, no. 5, p. 465-470.

MENDIAS, C., TATSUMI, R. and ALLEN, R., 2004. Role of cyclooxygenase- 1 and -2 in satellite cell proliferation, differentiation, and fusion. Muscle Nerve, vol. 30, no. 4, p. 497-500.

MONNOT, M., BABIN, P., POLEO, G., ANDRE, M., LAFOREST, L., BALLAGNY, C. and AKIMENKO, M., 1999. Epidermal expression of apolipoprotein E gene during fin and scale development and fin regeneration in zebrafish. Developmental Dynamics, vol. 214, no. 3, p. 207-215.

MONTES, GS., BECERRA, J., TOLEDO, O., GORDILHO, M. and JUNQUEIRA, LCU., 1982. Fine structure and histochemistry of the tail fin ray in teleosts. Histochemistry, vol. 75, no. 3, p. 363-376.

MUSCARÁ, M., MCKNIGHT, W., ASFAHA, S. and WALLACE, J., 2000. Wound collagen deposition in rats: effects of an NO-NSAID and a selective COX-2 inhibitor. British Journal of Pharmacology, vol. 129, no. 4, p. 681-686.

POSS, K., SHEN, J. and KEATING, M., 2000a. Induction of lef1 during zebrafish fin regeneration. Developmental Dynamics, vol. 219 , no. 2, p. 282-286.

POSS, K., SHEN, J., NECHIPORUK, A., MCMAHON, G., THISSE, B., THISSE, C. and KEATING, M., 2000b. Roles for Fgf signaling during zebrafish fin regeneration. Developmental Biology, vol. 222, no. 2, p. 347-358.

QUINT, E., SMITH, A., AVARON, F., LAFOREST, L., MILLES, J., GAFFIELD, W. and AKIMENKO, M., 2002. Bone patterning is altered in the regenerating zebrafish caudal fin after ectopic expression of sonic hedgehog and $b m p 2 b$ or exposure to cyclopamine. Proceedings of the National Academy of Sciences of the United States of America, vol. 99, no. 13, p. 8713-8718.

RATCLIFFE, A., AZZO, W., SAED-NEJAD, F., LANE, N., ROSENWASSER, M. and MOW, V., 1993. In vivo effects of naproxen on composition, proteoglycan metabolism, and matrix metalloproteinase activities in canine articular cartilage. Journal of Orthopaedic Research, vol. 11, no. 2, p. 163-171.
RILEY, G., COX, M. and HAZLEMAN, B., 2001. Inhibition of tendon cell proliferation and matrix glycosaminoglycan synthesis by no-steroidal anti-inflammatory drugs in vitro. Journal of Hand Surgery, vol. 26B, no. 3, p. 224-228.

SADOWSKI, T. and STEINMEYER, J., 2001. Effects of nonsteroidal antiinflammatory drugs and dexamethasone on the activity and expression of matrix metalloproteinase-1, matrix metalloproteinase- 3 and tissue inhibitor of metalloproteinases- 1 by bovine articular chondrocytes. Osteoarthritis and Cartilage, vol. 9 , no. 5, p. 407-415.

SANTAMARÍA, J. and BECERRA, J., 1991. Tail fin regeneration in teleosts: cell-extracellular matrix interaction in blastemal differentiation. Journal of Anatomy, vol. 176, june, p. 9-21.

SANTOS-RUIZ, L., SANTAMARÍA, J., RUIZ-SÁNCHEZ, J. and BECERRA, J., 2002. Cell proliferation during blastema formation in the regenerating teleost fin. Developmental Dynamics, vol. 223, no. 2, p. 262-272.

SMITH, R., KAJIYAMA, G. and LANE, N., 1995. Nonsteroidal antiinflammatory drugs: effects on normal and interleukin 1 treated human articular chondrocyte metabolism in vitro. The Journal of Rheumatology, vol. 22, no. 6, p. 1130-1137.

SOLHEIM, L., RÖNNINGEN, H. and LANGELAND, N., 1986. Effects of acetylsalicylic acid and naproxen on the synthesis and mineralization of collagen in the rat femur. Archives of Orthopaedic and Trauma Surgery, vol. 105, no. 1, p. 1-4.

SRINIVAS, G., CHICHESTER, C., BARRACH, H. and MATONEY, A., 1994. Effects of certain antiarthritic agents on the synthesis of type II collagen and glycosaminoglycans in rat chondrosarcoma cultures. Agents Actions, vol. 41, no. 3-4, p. 193-199.

WHITE, J., BOFFA, M., JONES, B. and PETKOVICH, M., 1994. A zebrafish retinoic acid receptor expressed in the regenerating caudal fin. Development, vol. 120, no. 7, p. 1861-1872.

ZODROW, J. and TANGUAY, R., 2003. 2, 3, 7, 8-Tetrachlorodibenzo-p-dioxin inhibits zebrafish caudal fin regeneration. Toxicological Sciences, vol. 76, no. 1, p. 151-161. 